Florida International University

FIU Digital Commons

3-21-2019

\title{
I am a Monster: An Exploration of the Self through Examination of Fragmented Identity or Mary Shelley's Frankenstein Becomes a Guide for Self-Reflection
}

Sherri A. Ahern

Florida International University, saher001@fiu.edu

Follow this and additional works at: https://digitalcommons.fiu.edu/etd

Part of the English Language and Literature Commons

\section{Recommended Citation}

Ahern, Sherri A., "I am a Monster: An Exploration of the Self through Examination of Fragmented Identity or Mary Shelley's Frankenstein Becomes a Guide for Self-Reflection" (2019). FIU Electronic Theses and Dissertations. 4043.

https://digitalcommons.fiu.edu/etd/4043

This work is brought to you for free and open access by the University Graduate School at FIU Digital Commons. It has been accepted for inclusion in FIU Electronic Theses and Dissertations by an authorized administrator of FIU Digital Commons. For more information, please contact dcc@fiu.edu. 


\section{FLORIDA INTERNATIONAL UNIVERSITY}

Miami, Florida

I AM A MONSTER: AN EXPLORATION OF THE SELF THROUGH

EXAMINATION OF FRAGMENTED IDENTITY

OR

MARY SHELLEY'S FRANKENSTEIN BECOMES A GUIDE FOR SELF-

REFLECTION

A thesis submitted in partial fulfillment of the

requirements for the degree of

MASTER OF ARTS

in

ENGLISH

by

Sherri Ann Ahern

2019 
To: Dean Michael R. Heithaus

College of Arts, Sciences and Education

This thesis, written by Sherri Ann Ahern, and entitled I am a Monster: An Exploration of the Self through Examination of Fragmented Identity or Mary Shelley's Frankenstein Becomes a Guide for Self-Reflection, having been approved in respect to style and intellectual content, is referred to you for judgment.

We have read this thesis and recommend that it be approved.

James M. Sutton

Michael P. Gillespie

Maneck H. Daruwala, Major Professor

Date of Defense: March 21, 2019

The thesis of Sherri Ann Ahern is approved.

Dean Michael R. Heithaus
College of Arts, Sciences and Education

College of Arts, Sciences and Education

Andrés G. Gil

Vice President for Research and Economic Development and Dean of the University Graduate School

Florida International University, 2019 


\section{DEDICATION}

First and foremost, I dedicate this thesis to my parents, Richard and Devi Ahern. Without your understanding, support, acceptance, and most of all, love, this endeavor would have not been possible. Lord knows you have gone through hell and have bent over backwards to provide me with everything I need to be comfortable and successful. I love you. We've come a long way since $29^{\text {th }} / 212^{\text {th }}$ Street!

To my master's cohort and Graduate English Association (GEA), thank you for encouraging me and trusting me to lead you. I did not expect to be so loved and welcomed by my peers in higher education. Special thanks to Ismael Santos (Vice President and magical mascot), Danny Fernandez (Secretary and little brother), Crystal Veber (Communications Director and resident teacher extraordinaire), Rodney Castillo (Treasurer and head advisor), and Amanda Estevez (Representative to Council for Student Organizations and the heart of our club).

To my esteemed professors, I have learned so much from you. You are the backbone of this department, and I, for one, have grown immensely from your guidance, patience, and understanding. In order of appearance: Thanks to Professor Sutton for being my official/unofficial advisor, therapist, and friend for almost fifteen years. To Professor Dickson for assuring me that the way I access Shakespeare is valid. To Anonymous who told me to switch majors--that advice drove me to try even harder with English. To Professor Strycharski: Thanks for seeing beyond my meek exterior and giving me some of the best advice, "You're 
not in competition with your classmates; you're in competition with yourself." To Professor Gillespie who prepared me to be... prepared, and instilled in me a confidence for presenting that I will always keep. To Professor Rochelson who is someone whom I hope to model myself after, with your mix of intellect and community service/activism. To Professor Blatt for showing me that teaching and learning are, in fact, one and the same, and that the classroom can be a playground where learning also takes place. To Professor Luszczynska who introduced me to theory and expanded my understanding of what literature and life are. To Professor Milbauer for helping me realize that my family's history is told through the stories of other immigrants and exiles. To Professor Daruwala for taking a chance on me and propping me up when I was crumbling-you are a truly special person. To Professors Golden and Grant for being teaching mentors of the highest caliber. To Professors Chinelly and Harrison who have set me on my future path with the confidence and tools I need to be the type of teacher I want and need to be. To Natasha Neckles whose computer-like knowledge of the English Department was matched only by the size of her heart.

To Mario Funk for your willingness to always lend a helping hand no matter the situation, and for walking with me through trepidation as much as contentment.

To my Panthers for Recovery and HAA families, where would I be without you? Special thanks to Thomas Guerra and Mari DeLacey for being my life coaches as much as they are my friends. 
To Michael Vensel who provided me with encouragement and a special place to work with furry friends to keep me company. You house was a home to me too.

To Veronica Perez who has been one of my cheerleaders through thick and thin, no matter what, for many years. You are my ride or die.

To Gabriel Seiglie of Graduate Linguistics Association for helping me in the final stages of this thesis and in general even though you were going through so much in your own life. You listened and had patience. For that, I am grateful. Last but certainly not least, a very special thank you goes to my BFF Arwa Bager. You never gave up on me throughout our 15+ years of shenanigans and growing pains. You are the gorgonzola pasta to my gorgonzola pizza. 


\section{ACKNOWLEDGMENTS}

I wish to greatly acknowledge the members of my committee, Professors Daruwala, Sutton, and Gillespie, for their continued support, not only with my schoolwork, but also with my personal life. They are truly saints in my eyes! Each of them made me feel capable and accepted in different ways, and that is truly more than I could ever ask for. To the office staff, Natasha Neckles, Gretter Machin, Cora Fernandez, Roxanne Timon, and Christian Gomez: you are the gears that keep our department running. Through the general coursework of the English Department, I have found a way to self-reflect in a most meaningful way during a very prosperous yet trying time in my life, so I am grateful for the hardworking, dedicated faculty and staff who make English exciting and insightful.

A very special acknowledgment goes to my city, Miami, Florida, for nurturing me and allowing me to flourish in this crazy place that I call home. You are my inspiration for all the work I do. 
ABSTRACT OF THE THESIS

I AM A MONSTER: AN EXPLORATION OF THE SELF THROUGH

EXAMINATION OF FRAGMENTED IDENTITY

OR

MARY SHELLEY'S FRANKENSTEIN BECOMES A GUIDE FOR SELF-

REFLECTION

by

Sherri Ann Ahern

Florida International University, 2019

Miami, Florida

Professor Maneck H. Daruwala, Major Professor

The purpose of this thesis was to explore the ways a fragmented identity can be reconciled through examination and analysis of Mary Shelley's

Frankenstein and several other works of art. Findings suggest that identity is both generated by and projected onto individuals, and reconciliation of these questions can turn the concept of monstrosity from a negative to a positive. This research supports and promotes the notion that individuals are more than simply the sum of all their parts, and that identities can simultaneously endure the paradox of being fragmented yet whole. 


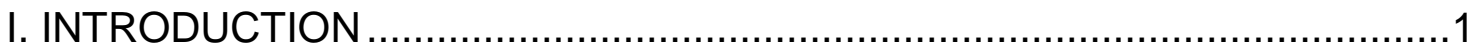

a. The Event on which this Fiction is Founded................................... 4

b. The Life and Times of Mary Shelley...............................................

c. I Am a Monster ........................................................................

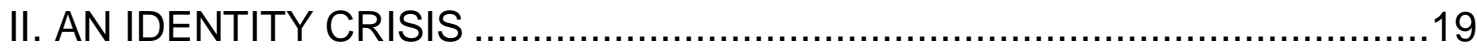

a. From Mary Shelley to Mary Brickell ...........................................19

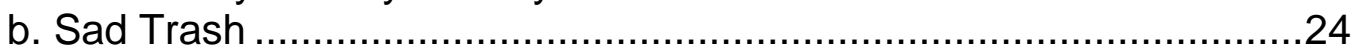

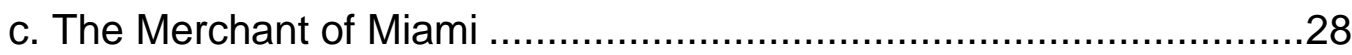

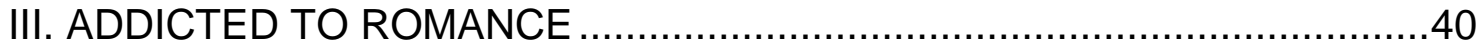

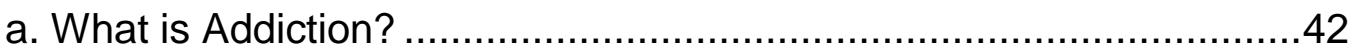

b. Yeats, Rossetti, and Company .................................................44

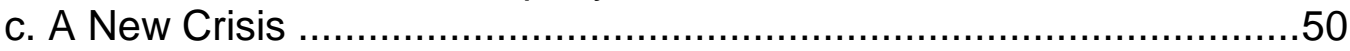

IV. PARADOXES: WHERE DO I BELONG IN THE SCHEME OF LIFE?.........53

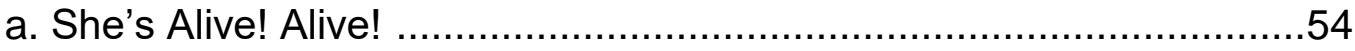

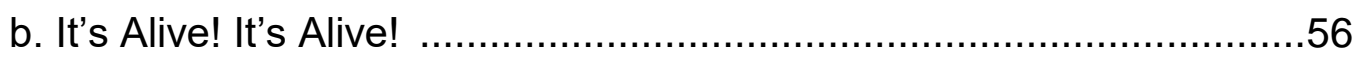

V. POP CULTURE

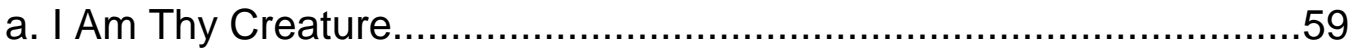

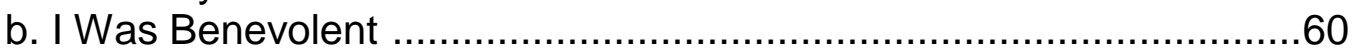

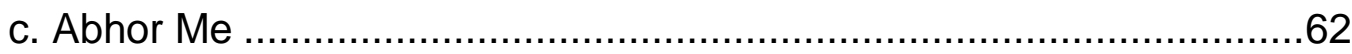

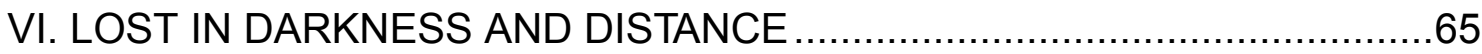

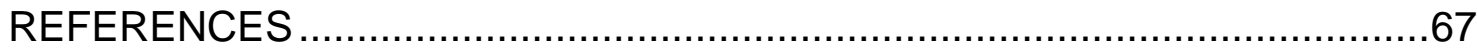




\section{INTRODUCTION}

What am I? This is a thought that I have so frequently that it is not so much a question as it is a state of being. Because of this ongoing internal battle of my identities, I have decided to compose this writing as a mixture of literary analysis and memoir. With that, the purpose of this thesis is to explore the ways in which my identity, and the identities of those like me, are explained and acknowledged in Mary Shelley's novel, Frankenstein. My research supports the concept that individuals are more than simply the sum of all their parts, and that identities can be fragmented yet produce something extraordinary. I grew up an otherwise happy child, but I grappled with my mixture of ethnic, cultural, and religious backgrounds, just to name a few. I never felt I was a whole person; I had to represent the varied parts of myself in different circumstances, not ever being able to understand that I was wholly good enough for any one situation. I could not put my feelings into words until I began to study Frankenstein. I was a monster.

Later in my thesis, I will bring up Miami, Florida, a place that has evolved into a city that cannot be essentialized simply because of the backgrounds of the residents who reside here, but can rather be looked at as a moving, breathing thing that has essential parts. It too is monstrous.

Several smaller works in conjunction with Frankenstein will be examined to gain a varied view of identity issues that characters encounter and how that relates to modern identity issues that I personally face along with the citizens of 
Miami. For example, William Shakespeare's The Merchant of Venice is concerned with religious and racial identity, but the play also reminds us that regardless of the gaps of time between those works and now, not much has changed with identity questions. Through analysis of literary and pop culture sources, readers may begin to reconcile a monstrous identity, or selffragmentation, and adapt monstrosity to fit a multifaceted identity that encompasses both old and new identities to form a completely different, perhaps more constructive, view of the self.

In Mary Shelley's iconic novel Frankenstein, the audience goes on a harrowing journey with Dr. Victor Frankenstein and his seemingly abominable creature which he has strung together in his "workshop of filthy creation" (Frankenstein 32). Victor pushes the bounds of science and ethics to create what will inevitably become his arch nemesis. As the years progress after the 1818 publication of the novel, the characters in the book begin to take on different identities as the story is retold throughout the past 200 years. We have cartoons, movies, and, of course, nightmares, all drawing from Shelley's source material. A simple Google.com image search of "Frankenstein" yields intimidating movie posters of Boris Karloff from the 1931 film rendition; however, it also includes a search for "Frankenweenie," a children's film about a boy who brings his beloved dog back to life. The range of results exemplifies how widespread Mary Shelley's reach has come to be. 
For anybody who has read the original book, it is fairly noticeable that key elements of the story and characters drastically change from the novel's publication until now. In the plays which were produced after the book was released, the originally-unnamed monster shifts to "Frankenstein" and Victor becomes the evil/mad scientist figure. Moreover, the once eloquent and thoughtful creature becomes a groaning, rampaging thing that terrorizes the townspeople. Nowadays, adding "franken-" to the beginning of a word makes it have a connotation of being ruined by unethical scientific practices. Thus, Mary Shelley's Frankenstein holds up as a symbol of the proverbial "identity crisis." In a country where DNA testing kits are quickly becoming a rite of passage, keen readers already understand that authors like Mary Shelley have always been privy to how complicated a role identity plays in life. Consequently, readers like me find a reflection of themselves glaring back at them, watery eyed, from the pages of the novel. I am Frankenstein's monster.

Ultimately, with this thesis, I intend to challenge the status quo and concentrate part of my writing on my own personal connection to Mary Shelley and her work in addition to conventional analysis. From the moment I read the novel, I was inexplicably drawn into her writing, the reasons for which I did not completely understand at the time. As I delved into my original research, I began to appreciate that I personally identified with several characters in the novel, including Victor, the creature, Justine, and Mary Shelley herself. Like the characters and the author, I, myself, have often felt torn between two worlds. I frequently find myself burdened with fitting into the "other" category. Similarly, I 
have found these traits in characters from works like The Merchant of Venice. My thesis will not only be an exploration of the novel and corresponding writings, but also an exploration of myself because that is precisely what graduate school in general has been for me. Novelist Libba Bray once said, "Write like it matters, and it will." I intend to do just that.

\section{a. The Event on which this Fiction is Founded}

Even though my own core focus of this thesis is to make a fearless and searching attempt to recognize and reconcile my various identities through analysis and comparison of several pieces of literature and pop culture sources, mostly Mary Shelley's novel Frankenstein, I find it necessary to begin with a general view of the life of author herself, the Mother of Science Fiction. I will investigate the basics and basis of the novel and its background through historical and biographical views of the author and her work because she undoubtedly had a peculiar and chaotic childhood and young adulthood. Her upbringing, fascination with and knowledge of contemporary science, and how events of her somewhat forlorn life may have been an influence in her novel will be discussed. These events are important since they frame the work in a specific time in which Mary experienced much tragedy in her own life; what is more, it was a period of great scientific discovery, when the line between ethics and advancement was blurred.

The goal of the following section is two-fold: to explore events in her life that may have influenced her writing, and to examine her access and understanding of contemporary sciences. The segment should set a foundation 
for the rest of my thesis and allow the reader to understand and appreciate Mary Shelley's life in the same way that I do.

Furthermore, since Mary Shelley's husband Percy Bysshe Shelley was indeed a noteworthy author himself, he is often referred to by their last name Shelley, so in an attempt to separate and individualize Mary Shelley, I will sometimes refer to her as simply Mary for the duration of this work.

b. The Life and Times of Mary Shelley

"To examine the causes of life, we must first have recourse to death." -Victor Frankenstein

Mary Shelley, the iconic writer of the gothic novel Frankenstein, undoubted had a lively yet tragic life. Both of her parents were intellectuals and famous writers: her father was a philosopher and journalist, and her mother was a feminist philosopher who is still highly regarded today in the world of women's rights. It would seem that Mary was destined to carry on the legacy of her parents. She intently read her parents' work and used it as a guide for her own writing. Mary would eventually meet and obtain inspiration from another writer, her future husband, Percy Bysshe Shelley. Their courtship would begin the extraordinary slippery slope that would lead to the production of Frankenstein. Although Mary had a scholarly childhood, accompanying her father to educational lectures and studying languages and sciences, all of which would find significance in her writing, she also unfortunately would grow to inherit much tragedy which would impact her novel. In addition to the dreary summer of 1816 spent telling ghost stories with friends in Geneva, Mary Shelley had many 
inspirations for her novel, but arguably some of the predominant ones were her knowledge of the sciences and the immense tragedy surrounding her family.

Allow me to start with a bit of background and expansion on Mary's life. In Ellen Moers' article, "Female Gothic: The Monster's Mother," she mentions that Mary's life was "remarkable." As we know, Mary's brilliant parents and friends, but she also read in five languages, including Latin and Greek (much like Victor Frankenstein himself), read Wordsworth and Gothic novels, chemistry and biology texts, and "sat by while Shelley, Byron, and Polidori discussed the new sciences of mesmerism, electricity, and galvanism, which promised to unlock the riddle of life..." (322). Though this information is vital in understanding the inner workings of Mary Shelley, it only scratches the surface. To this, Lawrence Lipking in "Frankenstein, the True Story; or, Rousseau Judges Jean-Jacques" asks the crucial question: "How did such a young and inexperienced writer, who in the remaining three decades of her life never again showed any phenomenal talent, manage to create a work that still haunts the dreams of the human race... Frankenstein is more than a book, as everyone knows; it is a myth and a symbol. What is its secret?" (417). Well, let us begin.

When she was younger, Mary Shelley attended public lectures with her father, William Godwin. He was a "social philosopher, political journalist, and religious dissenter who anticipated the English Romantic literary movement with his writings advancing atheism, anarchism, and personal freedom" (Britannica). The lectures were held at the Royal Institution, an educational facility dedicated to connecting the general public with science and science research (Royal 
Institution). One lecturer who specifically influenced Mary was the chemist Humphry Davy. Mary would later use his text, Introductory Discourse, about the future of human experimentation in which "man would 'interrogate Nature with Power'” (Holmes 183) as an influence for Frankenstein's character Professor Waldman of Ingolstadt. Of note, in his studies, Davy is credited with the "discovery" of Sodium and Potassium. He is the first person to isolate a sodium molecule through the process of electrolysis, or the "process by which electric current is passed through a substance to effect a chemical change" (Britannica). We can see above how the information about Davy, especially his work with electricity, finds its way into the book. Overall, much in the same way that Davy impacts Mary, Waldman will inspire Victor.

It would follow that electricity plays an important role in the story. Arguably, it is the catalyst that drives Victor to want to study science. After a "most violent and terrible thunderstorm," he witnesses a bolt of lightning, a "dazzling light," hit "an old and beautiful oak" (Frankenstein 23). For Victor is so interested in this occurrence, that he "eagerly inquired of [his] father the nature and origin of thunder and lightning." Alphonse Frankenstein explains to his son that the cause was "Electricity"' (24) and proceeds to conduct some experiments for Victor to see, including one with a kite that takes its influence from "Benjamin Franklin's famous experiment" (Frankenstein footnote 24). Consequently, Victor's father suggests that Victor attend science lectures. Victor later comments that the lecturer had "the greatest fluency of potassium and boron, of sulphates and oxyds...(24)." This line again recalls Davy's work. Even though Alphonse 
explains that the reason for the oak being decimated is electricity, the description that Victor gives in the book is somewhat complicated. He never outright says that lightning struck the tree, but rather explains, "On a sudden I beheld a stream of fire issue from" the tree. He continues, "So soon as the dazzling light vanished, the oak had disappeared, and nothing remained but a blasted stump" (23). It is curious to note that later in the book, the ruined Victor compares himself to that same blasted stump. The question then arises: is Victor the actor from whom much of the strife in the story stems, just as the stream of fire had issued from the tree, or is he just an innocent bystander that fate has chosen to strike with lightning? Moreover, lightning is what welcomes Victor back home after he finds out that his brother William has been murdered by the creature. Though he is ushered to his hometown by an impending storm, surely foreshadowing the rest of his days, Victor comments on the aesthetic of the electric storm. He mentions, "During the short voyage I saw the lightnings playing on the summit of Mont Blanc in the most beautiful figures" (49). Forms of electricity then continue to be a theme throughout the novel.

Besides knowledge she gained from attending lectures about chemistry, Mary Shelley would have been aware of the theory of Vitalism, which was popular at the time, and many great thinkers had their firm opinions on the subject. According to the Routledge Encyclopedia of Philosophy, Vitalism is the belief that beings which are alive possess something fundamentally different than non-living objects. There are many questions surrounding this topic in the book, about why exactly the creature is different from all other creations. There is both 
a scientific and philosophical approach to this. Originally, Philosopher René Descartes asserted that living beings are no more than automata, or slightly more complex versions of machines. It is widely accepted that Vitalism was developed as a contrast to this idea. For example, scientists like Louis Pasteur, the creator of the pasteurization process, claimed that fermentation was a vital activity because yeast cells are alive yet need no oxygen to ferment. This process, therefore, to the extent of Pasteur's knowledge, gives some vital quality to the process. He also used Vitalism as an opposition to spontaneous generation (which is the notion that life can spring from anywhere, even where life had not been before), to support Vitalism. Pasteur reasoned that living things can only originate from other living things; hence, live organisms have some exceptional property that other objects do not (Routledge). In the novel, Victor proclaims, "One of the phenomena which had peculiarly attracted my attention was the structure of the human frame, and indeed, any animal endued with life" (31). It is clear that there is a push and pull among these theories in the novel. All of these questions come into play when we examine Victor's creation. At the beginning, the creature can be seen as an automaton, which was built and created at the hands of a composer with specifically chosen parts like "hair of a lustrous black" and "teeth of a pearly whiteness" (35), but at the same time, the creature is more than just a complicated machine: he is compassionate towards the De Lacey family, he reads literature, he feels remorse. Questions of Vitality come into play in the novel, especially since the monster's creator makes the 
biggest judgment of the them all: that his creation is not even a vital part of humanity and should have never been created.

Even though some other chemists of the time saw fermentation or other chemical reactions as just simple processes that happened on their own with no outside actor, some scientists interestingly used Vitalism as an explanation for an overbearing entity or power that controls life functions. Chemist Justus Liebig used Vitalism to explain the specific order in which chemical processes in living beings occur: Here, the theory is used to explain an otherwise inexplicable chain of events. Most pertinently, noted embryologist Hans Driesch believed that Vitalism was an entity which controls organic processes (Routledge). We can see how these perspectives are explored in Frankenstein, yet no solution is ever obtained by either Victor or the creature. In all, Mary Shelley's readers are infused with questions and knowledge regarding a blend of chemistry and theories of Vitality. Victor bundles all of this when he exclaims that "I collected the instruments of life around me, that I might infuse a spark of being into the lifeless thing that lay at my feet" (35).

As Mary began to write Frankenstein, she was experiencing new motherhood as well as several deaths in her family. The combination of birth and death is evident throughout her writing. In Ellen Moers' article, "Female Gothic: The Monster's Mother," Mores discusses how Mary's experience with being pregnant and subsequently losing her first-born child had substantial impact on Mary's work. Despite being surrounded by accomplished people in her life, what really "sets her apart from the generality of writers of her own time, and before, 
and for a long time afterward, [is] her early and chaotic experience, at the very time she became an author, with motherhood" (319). At sixteen, she is Percy Shelley's lover, unwed and pregnant. She is shunned by her family and society. After the death of her first child, Mary was steadily pregnant for much of the next few years; unfortunately, only one of her children would survive to adulthood. As a result, Moers argues that Mary's is a rather special case because "in the eighteenth and nineteenth centuries few important women writers, except for Mary Shelley, bore children; most of them, in England and America, were spinsters and virgins" (319). Though this quote is purely Moers' opinion, it still exemplifies Mary as a writer who is juggling motherhood with writing.

Within the chapters of the book, Victor can be seen as the parent of the creature which he creates. This relationship is made clear right before his creation comes to life, especially with certain language he uses which alludes to pregnancy and delivery. Victor says, "After days and nights of incredible labor and fatigue, I succeed in discovering the cause of generation and life." He continues, "After so much time spent in painful labour, to arrive at once at the summit of my desires, was the most gratifying consummation of my toils" (32). A few paragraphs later, Victor reveals that "no one can conceive the variety of feelings which bore me onwards, like a hurricane, in the first enthusiasm of success" (33). Although the birthing process is incredibly exhilarating and "so great and overwhelming" (32), Victor still abandons this "catastrophe" and "wretch" of a creature which he has designed (34). To this, Ellen Moers responds that the juxtaposition of creation and abandonment are what really sets Mary's 
work apart from her female contemporary writers. Moers notes, "Shelley's book is most interesting, most powerful, and most feminine: in the motif of revulsion against newborn life, and the drama of guilt, dread, and flight surrounding birth and its consequences" (320). She continues, "Frankenstein seems to be distinctly a woman's mythmaking on the subject of birth precisely because its emphasis is not upon what precedes birth, not upon birth itself, but upon what follows birth: the trauma of afterbirth" (321). Through the creation-process passages in Frankenstein, one can glimpse the inner workings of an author who is in the midst of dealing with the ups and downs of motherhood herself.

Incidentally, Frankenstein explores the whole spectrum between birth and death. Moers notes that "Death and birth were thus hideously mixed in the life of Mary Shelley as in Frankenstein's 'workshop of filthy creation"' (324). Arguably, the most important theme is death, which drives the plot of the story. Mary herself lost children and several family members throughout her life, specifically during the writing of Frankenstein. The death saga of Mary's life starts at the beginning of her own existence, the death of her mother. In the article "Was Frankenstein Really About Childbirth?" Ruth Franklin notes that Mary Wollstonecraft Godwin, Mary's mother, suffered an infection shortly after giving birth to Mary and died as a result. Before she went into labor, Mary Wollstonecraft Godwin wrote a letter to her husband saying, "I have no doubt of seeing the animal today." It is interesting to note that according to Sandra M. Gilbert and Susan Gubar in "Mary Shelley's Monstrous Eve," Mary "read her mother's writings over and over again as she was growing up" (330). Mary's 
reading of "her mother's work must have been painful, given her knowledge that passionate feminist had died in giving birth to her..." (330). Therefore, it is not a surprise that Mary uses the term animal in her own work, as perhaps an ode to her mother's writing, to refer to both the creature and also as a term of endearment Victor uses for Elizabeth. In the book, Victor exclaims, "My imagination was too much exalted by my first success to permit me to doubt of my ability to give life to an animal as complex and wonderful as man" (32). Later again, he refers to his creation as an animal: "the strange nature of the animal would elude all pursuit..." (51). In reference to Elizabeth, Victor states, "While I admired her understanding and fancy, I loved to tend on her, as I should on a favorite animal; and I never saw so much grace both of person and mind united to so little pretension" (20). These are examples of how the death of Mary's mother may have influenced the writing of Frankenstein.

We have learned that Mary read her mother's work; in fact, she extensively read the works of both of her parents. At some points of her life, it was the only access she had to either of them, for she had lost her mother at birth, and somewhat lost her father once she ran away with Percy Shelley and became pregnant with his child. Gilbert and Gubar continue that "in the years just before she wrote Frankenstein... and those when she was engaged in composing the novel, she studied her parents' writings... like a scholarly detective seeking clues to the significance of some cryptic text" (331). These writings "appear to have functioned as her surrogate parents, pages and words standing in for flesh and blood" (331). The authors note that Mary read criticisms 
of her parents' writing as well. These readings may have helped her acquire a more well-rounded view of them and to get an understanding of their writing and perhaps who they were as people. Notably, we see that like Mary, who is without her parents in her early days of pregnancy and motherhood, so is the monster alone in his early days of life. Victor, himself solitarily, labors away to assemble his creation. Mary clings to the literature of her parents (and books in general) as a way to cope with her hardships; the creature also has only literature to guide him in his early life, and from the very beginning of the book, the reader sees that Victors uses books to understand the world around him, even if his father does not agree with Victor's choice in authors. For Mary, the monster, and Victor, reading is a main connection to the world.

Marilyn Butler adds to this conversation in her article "Frankenstein and Radical Science." She supposes that not only is there the influence of Mary Wollstonecraft in Mary's writing, but the impact of William Godwin is also evident, especially in the section of Frankenstein where the creature is narrating his early days of birth, clarity of vision, and survival. Butler believes that this is an influence of Godwin's novel, The Inheritors, "where the Neanderthal narrator describes his first encounters with homo sapiens" (410). In addition to the literary influence William Godwin had on Mary's work, we see a different kind of impact he had: absent or overbearing parents. This theme can be seen in Safie's father, Justine's mother, Clerval's father, and even Victor's father to an extent. In all, Mary's father had several influences on her work, starting even from the dedication of her novel: "To William Godwin; Author of Political Justice..." (4). 
To put it briefly, Mary Shelley dealt with much loss in her life, but particularly around the time she was beginning to write Frankenstein in June 1816. The period was saturated with infant mortality and suicide. Between July of 1814 when a sixteen-year-old Mary goes away with Percy Shelley, and May of 1817 when she completes the novel, Mary experiences the death of her first child, two subsequent pregnancies, the suicides of her sister Fanny and of Percy's legal wife Harriet, and the strife caused by her other sister Claire's relationship and pregnancy with Lord Byron. Though this is a tumultuous time, a debatably positive event does take place: since Percy's wife is now out of the picture as of mid-December of 1816 , he and Mary officially wed in late-December (Moers 323). Ellen Moers adequately sums up Mary's jagged life surrounding the time of her writing the novel:

But nothing so sets her apart from the generality of writers in her own time, and before, and for long afterward, than her early and chaotic experience, at the very time she became an author, with motherhood. Pregnant at sixteen, and not a secure mother, for she lost most of her babies soon after they were born; and not a lawful mother, for she was not married--not at least when, at the age of eighteen, Mary Godwin began to write Frankenstein. So are monsters born. (319)

Truly, the most tragic of these events is one involving the snatching away of Mary's young career in motherhood, the loss of her first child so quickly after the baby was born. The little girl was scarcely one month old when she perished. She was never given a name, similar to Frankenstein's creation. Understandably, 
Mary writes her feelings of loss in her journals. Moers lists two of Mary's reflections from March 1815: "Find my baby dead. A miserable day." Later, "Dream that my little baby came to life again, that it had only been cold, and that we rubbed it before the fire, and it lived. Awake to find no baby. I think about the little thing all day. Not in good spirits" (324). A passage that mirrors this in the novel is when Walton's men find Victor nearly frozen and bring him aboard the ship. Walton notes,

I never saw a man in so wretched a condition...We accordingly brought him back to the deck, and restored him to animation by rubbing him with brandy... As soon as he shewed signs of life, we wrapped him up in blankets, and placed him near the chimney of the kitchen stove. By slow degrees he recovered, and ate a little soup, which restored him wonderfully. (14)

This passage represents Victor "coming back to life," paralleling Mary's journal entry. The incredible impact of family trauma coupled with the loss of her newborn child adds to the genuine feel of gothic angst within the pages of Frankenstein.

In the end, Mary Shelley, the Mother of Science Fiction, clearly used her life experience, especially with motherhood, birth and loss, to gain inspiration for her tale of Victor Frankenstein and his creation. Based on the book alone, one could imagine that the author was a fascinating and learned person, and not necessarily assume that the writer would be a teenager with an unfortunate past. Mary, however, was all those things: an avid reader and student of languages 
and the arts, having a keen fascination with emerging sciences of the time. On the surface, Frankenstein is a gothic romance with elements of mystery and horror, but when we dig deeper, the reader finds a vast and fertile landscape of perspectives and emotion. Ellen Moers sums up Mary's legacy well in saying that Mary Shelley was a unique case, in literature as in life. She brought birth to fiction not as realism, but as Gothic fantasy, and thus contributed to Romanticism a myth of genuine originality. She invented the mad scientist who locks himself in his laboratory and secretly, guiltily, works at creating human life, only to find that he has made a monster. (320)

All of these elements and more added fuel to her Modern Prometheus and solidified Mary Shelley's place in literary history.

\section{c. I Am a Monster}

All that being said, why does it matter that a teenage girl wrote a novel 200 years ago, and a person living in the modern age would become fascinated enough with it to concentrate her main effort of study on it? Why, of course the obvious answer is that it is a fascinating and horrifying story that simultaneously tugs at the heart strings. However, my key reason is because this book helped me begin unpacking my deepest and longest-held question:

\section{What am I?}

This query has come up often in my life. I have always questioned who I am, and because of that, I have never felt "whole." I believe that I have a fragmented identity that I am only coming to terms with as of late. I, like Frankenstein's creature, am made up of various incongruous parts. To illustrate, I 
am a first-generation college graduate, a first-generation Miami native, the product of an interracial and interreligious relationship, and the embodiment of many other intersections. Some of these will be discussed later in this work. However, my studies within the English Literature Master's program here at Florida International University (FIU) have helped to solidify the notion that these seemingly mismatched puzzle pieces of myself are not what makes me "broken," but rather, I have started to realize that they work together to make me whole. The fragments of myself are what makes me a multidimensional human being who, despite the many shortcomings of life, is able to be of service to my family, friends, community, and school. However, as previously mentioned, I did not always feel this way, but throughout my graduate career at FIU, I have had the ability to examine the phenomenal literature that the English Department faculty assigns, and to uncover myself through my readings. I chose to study Mary Shelley's Frankenstein as my thesis project in order to learn more about the exceptional tale that began a modern mythology, and because I felt at home inside the pages of the book. 


\section{AN IDENTITY CRISIS}

Being from Miami, Florida, has afforded me many opportunities, but it remains a love/hate relationship. Attending graduate school at a beautifully diverse college campus like FIU in Miami has allowed me to appreciate the many cultural, economic, linguistic, and social variations around me and has been a breeding ground for my venture into self-recognition. I identify as a multi-cultural, first generation American, child of an undocumented immigrant, and as a person

who has several learning disabilities, a hybrid of sorts. I used to believe I was just a set of unmatched parts hastily strewn together to form an incomplete thing. However, within the past few years, I have asked for the help that I needed and can say I am on my way to understanding and accepting myself. Additional information will be revealed later.

The following section presents examples of intersections of Miami and Frankenstein and includes further discussion of my own identification with the novel and how these connections have allowed me to delve not only into my understanding of the novel, but also of myself and where I live.

\section{a. From Mary Shelley to Mary Brickell}

The Stitch as the Hyphen

When I first read Frankenstein, I was inextricably drawn into the world that Mary Shelley had created. How was it that I could feel compassion for a madman who creates a blight upon humanity, and then also feel empathy for the creation? It was because I had finally found the different parts of myself collected into one novel written by an intelligent young woman. Though many of my questions are 
not answered in the novel, it still provides me with a safe-asking-space to dredge up some deeply-rooted questions I had about myself and dissect them in order to begin a healing process.

The unnamed creature of the book is a being with no homogenous origin to speak of. Two of the ways he forms his identity are through reading literature that he has acquired, and by observing the De Lacey family. Conversely, he has an identity thrust upon him by the terrified people he encounters. He is intellectually brilliant yet physically despicable to the townspeople who beat him and drive him away from his hovel. Like Mary Shelley and Victor Frankenstein who are motherless and displaced on and off throughout their young lives, the creature repeatedly finds himself homeless; he has no place to live, no family, no history, no mother to love him.

I, too, like perhaps many of us in Miami, often feel like a person with no home. I live in a country that sometimes does not accept me for who I am, yet I cannot return to the homes of my ancestors because I have no claim to those places. My father's family is Irish, and he grew up in New York. My mother's ancestors are from India, but she was born and raised in in Guyana and eventually found her way to New York. Both of my parents have particularly humble roots, yet I listen in awe to their stories of "back home." I developed a sense of nostalgia for those times and places that were before I existed, for my imagined homelands. That false homesickness sometimes widens the rift that I have between me and my own community. Whether these false memories evoke positive or negative feelings, the facts remain that I am the product of the exile, 
the immigrant; I am the in-between. Frankenstein's monster also lies somewhere amid living and dead, soulless and soulful, amoral and righteous, intellectually beautiful and physically hideous. He is the hyphen that separates yet embodies everything that is right and wrong with human nature. Forasmuch as the creature is me, the creature is Miami.

Indeed, it is no secret that people of Cuban decent make up one of the most prevalent cultural groups in Miami, and so the book, Life on the Hyphen: The Cuban-American Way, by Gustavo Pérez Firmat is a valuable example of how to characterize what many have strong feelings about when it comes to modern identity issues. The author questions, "Have American-born or Americanraised Cubans created a culture, an exile-engendered mix of style and substance distinct yet not yet divorced from the Cuban condition and the American way? (172)." Miami-Cuban identity is then somewhere between the metaphysical and the physical; their culture, in a sense, also lies on the hyphen. It is both new and old, unbalanced yet perfectly symmetric. And even though Pérez Firmat's book focuses on the Cuban-American experience, it may be applicable to anyone who is on the border between what they identify themselves as and the new culture they have been transplanted into. For example, one of the ways I identify myself is Indian-Irish, but in that combination, I also find my American identity.

Mary Shelley, like many modern readers, experienced questions of her own identity and many traumas. Grief, loss, instability, and impermanence of home were prominent in her young life. Those feelings were translated onto the page, especially in the pathos with which Mary imbued her work. And so, like me, 
writing a thesis to try to explain my inner soul, Mary is the examiner and the analyst of her own conscience. She is her own kind of psychologist, putting into words her feelings the best way she knows how.

In "Frankenstein: Representing the Emotions of Unwanted Creatures," Laura Ortis mentions how according to some disability studies theories, a person with a disability will feel a sense of normalcy and community belonging if society treats them as such. Ortis cites researcher Ami Li's disability studies interpretation of the novel: Li notes that "rage is not inherent to abnormal bodies, but rather arises in relation to a hostile world." Ortis interprets this in the context of the novel as, "Only after the creature is shunned and learns how humans define beauty does he conceive of himself as ugly" (22-23). Therefore, once a monstrous, incapable, unworthy, identity is forced onto a person with a disability, that person may begin to take on that involuntary personality, in a vicious cycle of a self-fulfilling prophecy. We see this in the novel when the creature is shunned by almost everyone he encounters including his own creator. Despite the literature the creature has read, and observation of the De Lacey family, he is forced to project the hatred that been thrust onto him and then begins his rampage of destroying everything (and everyone) Victor holds dear.

Laura Ortis' words resonate with me for two reasons: First, I am a person with several intellectual disabilities, and l've lived my life with all the implications and self-doubt that entails. When I first started graduate school, I went through a battery of tests to pinpoint why I was always behind in my coursework. The results of those tests were a double-edged sword. On one hand, I now knew that 
I had a form of Attention-Deficit/Hyperactivity Disorder (ADHD), Dyslexia, reduced reading speed, and severe math difficulties; this proved to me that I was not "stupid," but I just had some things going on with my brain that were not my fault. On the other hand, these diagnoses meant that I had to deal with this head on.

Second, as a person who looks the way I do, living in Miami, I often have another identity projected onto me: a racial or cultural one. Oftentimes, people assume I am Hispanic and begin to speak Spanish to me because of my features and skin tone. I feel like I am forced to live my life under a false identity (some people have even gotten mad at me for claiming to not be Hispanic!). Granted, in Miami, it usually takes a bit of interaction with others to reveal what is underneath someone's exterior. Lamentably, this is a privilege that Victor's creation is rarely afforded.

Like the unnamed creature in the novel who finds himself a blend of human and monster, perpetrator and perpetrated, both he and I strive to be "normal," but neither of us grasps what exactly that means! Nevertheless, when readers contemplate the complications of this novel and also consider the differences of identity that bring us together to make Miami a whole, we must understand that even though we have our cultural differences, the puzzle pieces that do not quite fit together, it is our similarities as immigrants, as embodied borders, as hyphens, that really connect us to each other and also to Frankenstein. The text pleads with us to investigate our own origins and ask ourselves, what are we? How much do we rely on what links our presents and 
pasts? Of course, this is left to each audience member to decide, but the novel has the power to get its readers thinking about their own identities.

b. Sad Trash

When I am in Miami, I feel my identity issues, though ever present, are somehow more easily dealt with. They reside mostly in the back of my mind while I go about my day in this familiar place. But when I travel, many of my selfconcerns are brought to the forefront of my consciousness, especially when I am in places where the majority of people have lighter skin than I do. This is not to say that I feel uneasy around these people or that they are evil or anything else, but I am still on high alert about how I look and feel. You see, being half White but not really looking as though I am has always been a point of contention for me. I have always felt as though I was never "White enough" for one side of my family and never "Brown enough" for the other. When I am in situations like that, it also aggravates my learning disability symptoms, and the cycle of anxiety from being "the other" is renewed.

Nonetheless, while attending the Grand Valley State University Shakespeare Conference and Festival at the end of 2018 in Allendale, Michigan, I was set to present on one of my favorite William Shakespeare plays, The Merchant of Venice in a pedagogical context. I was to note that my two main personal tools I use for understanding Shakespeare's work, or any other literature, are accessibility and identification. I chose to focus on how those two elements factor into the challenges of teaching in Miami. The first section of my presentation was an anecdote about an encounter I had in my "Shakespeare in 
Miami" graduate class taught by Doctor James Sutton. It was a wonderfully enlightening class and set a strong foundation for my exploration into how my home city factors into my identity and how I can use Miami as a lens to view Shakespeare's work. Though I deal with "Imposter Syndrome," I have not had my intelligence and disabilities challenged as much as I did in one of the sessions of that class.

To illustrate: We had some community educators join us to share their practices in teaching Shakespeare to middle and high school students. The first teacher to speak exclaimed that he believed teaching the plays from No Fear Shakespeare editions was the "wrong" way and somehow cheapened the learning experience. Of course, I turned bright red and shuffled my own copy of No Fear Shakespeare: The Merchant of Venice under a pile of papers. To clarify, No Fear Shakespeare books are editions of plays in which the original text is printed on the left page, and a "modern translation" is printed on the right page. At that moment in class, I felt intellectually attacked, I felt stupid, and I felt unworthy to be sitting in the same classroom as my peers and these other teachers.

But why should the way that I approach Shakespeare be criticized? No Fear Shakespeare gives me accessibility to the writing, especially with my reading difficulties.

As I remember back to my first class as a graduate student, I asked Doctor Vernon Dickson if it was acceptable that I use No Fear to help me write essays in his "Shakespeare and Film" class. His answer was along the lines of 
"yes, why not? Some editions are better than others depending on the author/translator, but there is nothing wrong with that." So ever since then, I have used No Fear, and I have also incorporated whatever means work best for me in order to understand the content, including watching videos of plays or attending as many live productions as possible.

I try to instill in my own students that any avenue you can take to better understand your schoolwork, the world around you, and yourself is worth pursuing, even if by unconventional means. My theory applies especially to Miami where we have a prodigious mixture of backgrounds, so there exists an array of perspectives on literature, culture, and language. I was prepared to talk about all these things in my presentation at Grand Valley.

To resume, before my presentation at Grand Valley, unfortunately, the familiar feeling of not-belonging was compounded. The keynote speaker of the conference, a scholar from the Folger Shakespeare Library, held an acting and directing workshop. He started with a giant projection of the cover of a No Fear Shakespeare book. He told the entire conference audience that it was unacceptable to teach using that book. Everyone chuckled and took pictures of the slide. But I could not stay quiet like I did the first time. I called him out: I told him and the rest of the audience very cordially yet seriously that I would be giving a presentation later that day on why I use and advocate for No Fear: my own disabilities plus being a teacher in a diverse place like Miami. A hush fell over the room. The keynote said he would attend my presentation because he was 
interested in learning my thoughts on the subject and wanted to speak further with me.

What are the odds that I would be dedicating a portion of my speech to No Fear Shakespeare, and would be shamed for using it, all in the same day? In the time between that public interaction and giving my presentation, I felt like a sham. Had I bamboozled my colleagues in academia? I was a foolish child who could not even read Shakespeare, a body of study that I have always enjoyed and to which I dedicated many hours of scholarship. I could feel everybody staring and judging. I was the creature being chased with pitchforks. I was a young Victor Frankenstein happily sharing with my father what I was reading, and academia, like Alphonse Frankenstein, had responded back, “...do not waste your time upon this; it is sad trash" (Frankenstein 22). Though I aim to reclaim and make positive what it means to be a monster, I still felt classically monstrous in those moments.

The keynote presenter never did come to my lecture, and in the closing speech of the conference the next day, he echoed the same sentiment: No Fear Shakespeare is unacceptable and has no place in the classroom. Luckily others noted this and spoke with me after to offer their support, mostly in whispers. Be that as it may, my presentation went surprisingly well and garnered much support from some and even changed the minds of others. In the end, I came away from that conference with a renewed vigor from sharing about my own monstrosity and being comfortable with it... even if others are not. 
Since we are on the subject of The Merchant of Venice, I would like to mention that before Mary Shelley appeared in my life, William Shakespeare was one of my first loves. I understand that Shakespeare is not universal (i.e., not everybody from every walk of life can identify with the plays), but for me, I can always find specific quotes that help me get through life. I particularly enjoy Merchant because of the questions of racial and religious identity. As it happens, I am a person who grew up with parents of two distinct faiths: My mother practices Hinduism, and my father grew up Catholic. Neither faith was imposed upon me. I was encouraged to find my own middle-ground (or not). I am thankful for the spiritual freedom that my parents afforded me; however, I do feel at a loss sometimes. I was left out of customs and rituals that could have enriched my life (I guess parents can never do anything right when they have picky children!). Part of my reconciliation with myself is that of a spiritual nature-not continuing to feel in-between and therefore left out--finding my own personal faith and becoming contented with that. Accordingly, as I have related Mary Shelley's writing to Miami and myself, I can do the same with this play. Both Frankenstein and Merchant are concerned with similar topics and therefore are a part of the same vein of thinking for me. The following section explains my thoughts on how the play links to Miami and to myself.

c. The Merchant of Miami

Cafecito, Croquetas, and Crushing Identity

The Merchant of Venice by William Shakespeare is a beloved yet controversial play. This work deals with social interactions between people of two 
different religious backgrounds. Characters struggle with their identities, especially Shylock and Jessica, the two primary Jewish characters in play. Shylock all but loses who he is at the end of the play, and Jessica questions her connections to her father's blood, even seeking conversion to Christianity. In Miami, this play holds a special significance. First, because of our large Jewish population (the third largest in the country), and second, because of the identity question of the play in general, and how other settlers, not just Jewish ones, can relate to the work. Miami is a place where the hyphen is king: many people identify themselves partly by where they come from and partly by where they are now. Some may consider themselves Jewish-Americans, while others are Miami-Cubans. Many of the residents of Miami share this commonality; therefore, it would make sense that Merchant would resonate with the local audience. Jessica's challenges with leaving her father's house to marry someone of a different background and faith, and Shylock's steadfast nature of keeping his traditions and religion intact in a place where he is made to feel "the other" are relatable in Miami. Unfortunately, certain people still see this play as simply a representation of anti-Semitism and want nothing to do with it. This will be an exploration of the complicated identities of the characters of the play, especially Jessica's, and also how that relates to a Miami audience since thinking about one's identity is a large part of local culture and scholarship.

In The Merchant of Venice, Shylock, a Jewish money lender, enters into a monetary arrangement with Antonio, a prosperous shipping merchant. This comes about because Antonio's close friend Bassanio believes he needs the 
money to travel to meet and court the rich and beautiful Portia. Antonio offers to borrow the money on behalf of Bassanio. Antonio, confident in his own shipping business and the money he will soon have when his ships arrive back home, is not fearful that Shylock has set a condition for late repayment as a pound Antonio's flesh. Shylock's lending the money to Antonio allows Bassanio the ability to travel to meet Portia and try to win her hand through a test that Portia's father concocted before his death. Moreover, Bassanio's friend Lorenzo plans to elope with Shylock's daughter, Jessica. This causes Shylock much anguish. Antonio's ships do not return on time, so Shylock tries to exact his revenge on Antonio, taking him to court and demanding a pound of flesh. Portia disguises herself and presides over the case. The end result is Antonio gets to keep his flesh, and Shylock must give up his wealth and convert to Christianity. In true Shakespeare fashion, the audience is left with a happy ending for most of the characters, but a crushing ending for Shylock, who has lost everything that makes up who he is.

The question of self-identity prevails in this text. Shylock is a Jewish money lender, who, as we have just seen, loses his identity and well-being by the end of the play. He is stripped of his Jewish identity by having to convert to Christianity, and he is also stripped of his money, something that defines his career. Additionally, he loses the closest family member he has, his daughter, because she escapes their household and elopes with Lorenzo. Antonio too may be looked at as someone who is on the verge of literally losing his identity by dying because of the removal of a pound of flesh. He is also not a good example 
of an upstanding Christian. Portia's character, even with the freedom to live how she wants, is still constrained by the will of her dead father about choosing whom she will marry.

Even though the play focuses on Shylock, questions of his daughter's identity are just as important. Jessica struggles with this throughout the text while other characters comment on her situation. These comments are almost always in relation to her father. Jessica has very little agency of her own: she belongs to her father at first, doing what he tells her to do and being an outwardly obedient daughter. Later, she ends up belonging to her suitor, Lorenzo. She asks him "For who love I so much? And now who knows / But you, Lorenzo, whether I am yours" (Shakespeare II.vi.30-31)? He responds, "Heaven and thy thoughts are witness that thou art" (II.vi.32). Though this can be seen as simply two young people professing their love to one another, it can also be Jessica giving up her identity, once again, to another man besides her father. Thus, "ownership" of Jessica is transferred from Shylock to Lorenzo.

Readers may assume that Jessica wants to leave her father because he is Jewish, and she herself does not want to be Jewish anymore. However, Jessica's motives for leaving him may be mixed. For example, when talking to Launcelot Gobo, Shylock's servant who now wants to leave his master's house to work for Bassanio, Jessica responds by saying "I am sorry thou wilt leave my father so. / Our house is hell, and thou, a merry devil" (II.iii.1-2). This can be viewed in two ways: that Jessica believes her house is hell because it is a Jewish household, or it simply illuminates that her father is not an easy man to live with 
in general. She concludes this interaction with Launcelot Gobo by scolding herself and looking forward to her marriage with Lorenzo that will perhaps change the way she feels:

Alack, what heinous sins is it in me

To be ashamed to be my father's child!

But though I am a daughter to his blood, I am not to his manners. O Lorenzo, If thou keep promise, I shall end this strife, Become a Christian and thy loving wife. (II.iii.15-19) Jessica here laments her shame for feeling negatively about her father, and her familial connection to her father. However, she thinks of her plan to escape with Lorenzo as a method to remedy her situation and lot in life: She will become a Christian and a wife to Lorenzo. In comparison to some other plays, such as $A$ Midsummer's Night Dream (which, granted, does have its own problematic content) where the lovers simply marry at the end of the play and that is that, here Jessica must consider another layer of why she is marrying and what that will change in her life and her identity. Later, Lorenzo comments on what a good person Jessica is and how if her father receives any good fortune it is because of his daughter. Lorenzo says, "If e'er the Jew her father come to heaven, / It will be for his gentle daughter's sake. / And never dare Misfortune cross her foot / Unless she do it under this excuse: That she is issue to a faithless Jew" (II.iv.3337). If Jessica converts to Christianity, she is still inherently linked to her father even if she will live as a Christian. 
In contrast to this scene, Salarino makes a different kind of judgment of Jessica. After Jessica and Lorenzo have eloped, Shylock discusses the news with Salarino, a friend of Antonio and Lorenzo. Shylock notes that Jessica will be eternally punished for her misdeeds: "She is damned for it" ... "My own flesh and blood to rebel!" (III.i.26, 28). Salarino responds, "There is more difference between thy flesh and hers than between jet and ivory, more between your bloods than there is between red wine and rhenish" (III.i.31-33). Here, Salarino views Jessica and Shylock as so dissimilar from each other that they can only be compared as opposites. It is interesting to see this view from a character who is arguably less important in the storyline than many of the other characters. It is also compelling to wonder if Salarino has this opinion of Jessica being so far removed from her father because he considers her more of a Venetian than he does Shylock, especially since she probably does not have many of the physical markers of being Jewish that Shylock has, such as clothing and hairstyle (Hirsch par. 19). Furthermore, Jessica shows that she can go against her father and perhaps prove Salarino's opinion right by planning an elaborate ruse so that she may escape her father's house and run away with Lorenzo. In this scene, Jessica does try to gain some agency, at least for a small amount of time while she is in transition from belonging to her father then to her suitor. Jessica disguises herself as a torchbearer boy and absconds with some of her father's riches in order to escape with Lorenzo. This small act of rebellion leads to big penalties, especially because of how much it hurts her father. But even in her defiance, Jessica is still conflicted about her decision: 
What, must I hold a candle to my shames?

They in themselves, good sooth, are too light.

Why, 'tis an office of discovery, love.

And I should be obscured. (II.vi.41-44)

Jessica is ashamed that she will be holding up the torch to her face when she does not want the world to see her and her misdeeds against her father.

In "Counterfeit Professions: Jewish Daughters and the Drama of Failed Conversion in Marlowe's The Jew of Malta and Shakespeare's The Merchant of Venice," Brett D. Hirsch explains that in Shakespeare's time it would have been complicated to fully convert from one religion to another, specifically from Judaism to Christianity. He notes that in the case of this play, Jessica would not be looked at in the same way as her father. She is racially white-seeming as opposed to Shylock who probably has stereotypical external characteristics of being Jewish, such as his beard and clothing. Hirsch asserts that

This argument, which has been put forward by a number of scholars before, rests entirely on descriptions of Jessica as "fair" and "gentle," suggesting a racial fluidity that simultaneously brings her closer to the Christian gentle/gentile community she longs to join whilst distancing her (physiologically and literally) from her father. (par 19)

Hirsch cites Ania Loomba as saying that many other converted female characters in plays of the time were notably fair-skinned, and that is what allowed their relatively smooth transition from one religious group to another. Hirsch then explains another way to view this situation: He argues that "fair" is used to 
describe female characters in this play as a testament to their financial worth as opposed to their skin tones. The play is about merchants and money lending after all!

A scene of note that involves Jessica being fairly assessed because of her financial worth is again the episode right before Jessica leaves her house to elope with Lorenzo. Before coming downstairs to meet with Lorenzo, Gratiano, and Salarino, she throws down a casket, or box, that is presumably filled with her father's riches. She also says that she will "make fast the door and gild myself / With some more ducats, and be with you straight" (II.vi.49-50). It is after observing this moment that Gratiano implies that Jessica is too nice to be a Jew. Lorenzo agrees:

Beshrew me but I love her heartily.

For she is wise, if I can judge her.

And fair she is, if that mine eyes be true.

And true she is, as she hath proved herself.

And therefore, like herself--wise, fair and true--

Shall she be placed in my constant soul. (II.vi.52-57)

Though Lorenzo is saying very kind words about Jessica and how much he loves her, he says these things at a pivotal point: when Jessica has just handed him money and is going to get more. This plays into the argument that when Lorenzo calls her "fair," he can mean it as nice, fair-skinned, or fairly-priced. He will win both her hand and her father's money, especially at the end of the play when it is stipulated that upon Shylock's death, Lorenzo will inherit all of Shylock's property 
as a part of the faux legal settlement. This is another glimpse into to how other characters view Jessica's identity.

To complicate these issues further, Hirsch mentions another scene with Launcelot Gobo and Jessica where he questions her conversion. Launcelot announces to Jessica, "Yes, truly, for look you, the sins of the father are to be laid upon the children... Therefore be o' good cheer, for truly I think you are damned" (III.v.1-2, 4-5). He continues to explain that there is only one way that Jessica will not be damned, and that is if Shylock is not her real father. Jessica explains that then she would be damned anyway because her mother would have been unfaithful; however, she mentions "I shall be saved by my husband. He hath made me a Christian" (III.v.16-17). Launcelot does not accept her answer. He notes that there are too many converted Christians already, and they are eating all the pork! Here, he implicitly puts the blame not only on the ones who are converting, but also the ones who are helping with it, like Lorenzo.

In Miami, we have a mixed culture with people from many different backgrounds who are dealing with identity questions each their own. Some wish for nothing more than to assimilate into what they perceive to be the American Dream but are rejected because of the way they look; others hope to keep every facet of their traditions from their home countries alive. In Merchant, identity questions have to do with cultural, religious, and racial backgrounds and how they affect one's current situation. Shylock, the local foreigner, is trying his best to maintain his original customs while living in a society that he does not necessarily agree with, and he succumbs to the taunts of the other characters. 
Jessica struggles with her familial roots, her new Christian identity, and the thoughts of betraying her Jewish father. She combats the hyphenated identity, trying to migrate from Jewish-Venetian, to simply a Venetian, as Christianity is the default there. She cannot so easily give up her identity though. As Launcelot Gobo implies, Jessica will not be a Christian, per se, but rather a converted Christian.

In Miami, although we have the third largest Jewish population in the country, it was not always like this. According to the article "Miami's Jewish History" by Marcia Jo Zerivitz, around 1913 is when the Jewish population began to grow on Miami Beach, but they were legally restricted to living south of Fifth Street. With a disastrous few years filled with Yellow Fever, population decline, two hurricanes, and the stock market crash, the media and the rest of the Florida and the United States deemed Miami "wiped out." But it was the Jewish people who lived here, and many more who migrated, that got Miami back on its feet and laid the foundation of what all residents enjoy today. Zerivitz's article notes that, by the mid-1930s The hotel, banking and construction industries escalated with greater participation by Jews, who also helped start Miami-Dade College and Florida International University, with a Judaic Studies Program. The 1930s also marked the dismantling on Miami Beach of restrictive barriers to Jewish ownership of real estate, as large numbers of Jews purchased properties from debt-ridden owners only too happy to sell them. While 
discrimination had by no means vanished, conditions were improving. (Zerivitz)

Some modern residents of Miami may think that the Jewish people have somehow always existed and prospered on Miami Beach, but looking at the exterior and not at the history of a people can lead to broad generalizations about such groups. After all, there is still anti-Semitism that happens almost daily here in Miami, despite the Jewish community being a part of the backbone of the city. These observations can also be applied to Shylock. The Venetians do not understand Shylock's history, nor do they put in the effort to understand it, so they rely on the local, derogatory, anti-Semitic "understanding" of who he is and treat him as such. It does not help that he is also financially successful because that makes him even more of a target for their animosity.

In a recent production of Merchant by Shakespeare Miami (now Florida Shakespeare Theater), director Colleen Stovall addressed the audience before the start of the show. She explained that she had received letters of discontent from residents about why she would direct such an anti-Semitic play, especially here in Miami with our large Jewish population. On the company's website, Stovall notes:

I do not see the play as antisemitic. It was revolutionary in its time - as Shakespeare wrote the character of Shylock to be a complete human being, not a caricature. The bad guys in this play are the Christians, and their cruel behavior is put forward for all to see. Not everyone knows that Shakespeare, himself, was fined for usury... 
Here, Stovall reveals that the play is certainly more complicated than some people understand, and that Shakespeare may have had some personal experience with its content. She continues by explaining how much research she put into the play before it was produced it and that she considered the feelings of her community, thus proving that this play takes an exceptional amount of effort to put on because of the layers of history it represents. When I saw the play for myself, it was the first time I had ever seen a live production of it, and in my own opinion, this is a play that must be seen in addition to being read to witness the true intricacy of it, to witness the struggles that each character faces, and to understand that identity is multifaceted.

In the end, when we consider the identity complications of this play and the differences that bring us together to make Miami a whole, I will restate that it is our shared experiences as opposed to our cultural differences that really connect us to each other, to Miami, and to the Merchant of Venice.

After all, in the courtroom scene at the end of the play, Portia's disguised character asks of Antonio and Shylock, "Which is the merchant here, and which is the Jew?" (IV.1.172), possibly implying that they look similar. It is a balance of these things, similarities and differences, that makes Miami so rich, and the play so applicable to the people here.

It is somehow reassuring to me that Mary Shelley and William Shakespeare were parsing through the same issues that I am now, and that we were/are working towards the same goal of understanding tense subjects and feelings by putting them into words. 


\section{ADDICTED TO ROMANCE}

Another major facet to my larger question of self is the topic of addiction and recovery. My foray into the world of Frankenstein and some other literature has been a component in helping me put into words certain painful feelings that I often thought were irreconcilable. In short: I am a person in long-term recovery. What that means to me is that I have not had an alcoholic beverage in two and half years; that through sobriety, I can be a be a more upstanding daughter, friend, and student; and I may help spread the message that recovery is possible. I did not always feel this way. I lived many years not understanding who I was, and not really caring. It is through recovery and my time in graduate school (which actually happened concurrently) that I have begun to analyze this piece of my identity that had been missing for so long. As a person in recovery, I am able to take a daring look at myself and begin recovering in all aspects of my life.

Through my experience with recovery, I have been able to help others who have the same ailment of addiction. Furthermore, I have the honor of being the president of the student organization Panthers for Recovery. It is one of the limited resources on campus that provide direct support to students and community members with substance and process use disorders. I have been given the opportunity to work with those who are often ignored or too embarrassed to talk to anyone else. Our outreach includes hosting four support meetings per week, various educational events, and fellowship activities like alcohol-free tailgates, fostering a safe environment for our members and allies. I have also been able to present at recovery-related conferences all around the 
United States, even winning a nation-wide scholarship to help develop recovery resources here on campus for our student veterans in recovery.

Addiction is something I scan for now while reading, and though we do not see much direct evidence of drug or alcohol abuse in the Frankenstein, there are certain behaviors present that are emblematic of addiction. In "Mary Shelley and the Power of Contemporary Science," Richard Holmes observes that Victor is "a romantic and idealistic figure, obsessive rather than evil, and determined to benefit mankind" (192). The key word here is obsessive. Victor is completely fixated on crafting his creature, but once his wish of bringing dead flesh back to life is fulfilled, he becomes terrified and shirks all responsibility for his actions in an attempt to escape reality. Victor recalls,

But I escaped, and rushed down the stairs. I took refuge in the court-yard belonging to the house which I inhabited; where I remained during the rest of the night, walking up and down in the greatest agitation, listening attentively, catching and fearing each sound as if it were to announce the approach of the demonical corpse to which I had miserably given life... I passed the night wretchedly. Sometimes my pulse beat so quickly and hardly, that I felt the palpitation of every artery; at others, I nearly sank to the ground through languor and extreme weakness. (Frankenstein 36) Mary may have known of the symptoms of addiction because she was audience to a person who was suffering from this disease: her husband, Percy Shelley. According to an article that will be discussed later in more detail, Percy was no stranger to opium, even using a form of it while courting Mary. 
Since one of my main objectives in everyday life is to reduce the stigma against people with substance/process use disorders, the following three sections introduce modern scientific research on addiction including updated findings and definitions, discuss opium references in selected Romantic era artists' works, and provide a synopsis of the current state of the American opioid epidemic.

\section{a. What is Addiction?}

Many people believe that the opioid epidemic is something new. However, the problem with addiction has practically always been around, but it was especially popular during the Romantic eras. That being the case, many artists from that time either dabbled in opium usage or were outright addicted. As stated, one of my areas of personal research is addiction and recovery, so I find it fascinating that there are allusions to drug use present in certain Romantic literature. Although we have come a long way in how we treat and diagnose opioid dependence, many of the attitudes towards the disease of addiction in general are the same as they were back then.

To begin to define addiction, let us start off with an entry from the 1880 edition of the Encyclopedia Britannica: it "happens chiefly in individuals of weak will-power, who would just as easily become the victims of intoxicating drinks, and who are practically moral imbeciles, often addicted also to other forms of depravity." This may seem shocking to some, but many people still hold on to this definition despite what current medical findings have established. To combat the stigma, here is one of the most recent psychological definitions of addiction: 
Addiction is a complex condition, a brain disease that is manifested by compulsive substance use despite harmful consequence. People with addiction (severe substance use disorder) have an intense focus on using a certain substance(s), such as alcohol or drugs, to the point that it takes over their life. They keep using alcohol or a drug even when they know it will cause problems. Yet a number of effective treatments are available, and people can recover from addiction and lead normal, productive lives. (Psychiatry.org)

Further, the Diagnostic and Statistical Manual of Mental Disorders, Fifth Edition or DSM-5

Recognizes substance-related disorders resulting from the use of 10 separate classes of drugs: alcohol; caffeine; cannabis; hallucinogens (phencyclidine or similarly acting arylcyclohexylamines, and other hallucinogens, such as LSD); inhalants; opioids; sedatives, hypnotics, or anxiolytics; stimulants (including amphetamine-type substances, cocaine, and other stimulants); tobacco; and other or unknown substances. (Hartley)

People tend to compartmentalize substance use disorders, but addiction and addictive behavior can be manifested in physical activity. These are called process use disorders. It is possible to become addicted to certain behaviors, such as spending money, gambling, eating, smartphone use, or sex. The American Psychological Association states that 
addiction involves repetitiveness, high frequency, and excessive use, whether the focus is a substance or a behavior. The same characteristics of a drug addiction - continuing use of the substance despite negative consequences, inability to stop using the substance even if it is desired, and cravings - also apply to a process addiction. (What is Addiction") Considering the 1880 definition and the current definitions of addiction, it is obvious that people of the Romantic and Victorian era did not understand the disease, but it is more forgivable because they did not have the scientific knowledge to understand it. However, it is saddening and sometimes maddening that people in this day and age, even with all the scientific research that exists, still hold on to the 1880 definition. Especially among the ethnically mixed community of Miami, I hear the "moral failing" or "will power" arguments far too often, and those are key reasons why many people here choose to not seek help. This unfortunately causes a plethora of other problems. We will delve into that point later.

\section{b. Yeats, Rossetti, and Company}

My first literary exposure to drug use was in my readings of the Sherlock Holmes stories by Arthur Conan Doyle and various Agatha Christie books where characters would often use drugs to cope with small ailments. In Doyle's The Sign of Four, Sherlock Holmes even agrees to take a bottle of cocaine as payment for a solved mystery. Therefore, when I was younger, opioid use seemed like it was a normal thing in the time periods that the books were written. I never really made the connection to the harsh reality of drug abuse: I did not 
understand the gravity of the effects on the characters, perhaps much like artists of the Romantic period did not want to see the dangers of taking drugs themselves.

In the article "Representations of Drugs in 19th-Century Literature" by Sharon Ruston, the author elucidates several ways that people would have acquired opioids and who may have used them. Writers including "Samuel Taylor Coleridge, Elizabeth Barrett Browning and Charles Dickens all used the drug, for pleasure or as medicine" (Ruston). The author further explains that in Coleridge's poem "Kubla Khan," the poet is specifically recalling an opium-induced dream. In the poem, the lines "And close your eyes with holy dread / For he on honey-dew hath fed, / And drunk the milk of Paradise" can be read as an experience with ingesting opium. Ruston continues,

"Kubla Khan" was finally published in its fragmentary state in 1816, nearly two decades after this dream, when it was clear that it would never be finished. In the same volume, Coleridge published "The Pains of Sleep," a poem originally written in 1803 while he was suffering the most agonising and terrifying nightmares as a result of withdrawal from opium.

Ruston continues her article by explaining some of the ways in which opium was served. She mentions that "Before the 1868 Pharmacy Act, 'barbers, confectioners, ironmongers, stationers, tobacconists, wine merchants' all sold opium," and authors who took it included "Elizabeth Barrett-Browning, Lord Byron, Wilkie Collins, George Crabbe, Charles Dickens, John Keats, Percy Bysshe Shelley, and Walter Scott"; that "Opium in particular was commonly and 
routinely prescribed for an alarming number of ailments to both children and adults, including 'nervous cough', hooping cough, inflammation of the intestines, toothache, dropsy and the hiccups." And that "Laudanum, the most popular form in which opium was taken (dissolved in alcohol) was recommended in cases of fever, sleeplessness, a tickly cough, bilious colic, inflammation of the bladder, cholera morbus, diarrhoea, headache, wind, and piles, and many other illnesses." Access to opium and the number of illnesses it treated made the drug a seemingly safe choice for both young and old.

In comparing "Kubla Khan" and "The Pains of Sleep," Ruston understands that they "[demonstrate] the starkly different ways in which drugs were represented in literature of the 19th century." I believe that this tradition is still carried on till today: where artists of all kinds represent the dichotomy of drug use (beautiful and mind-expanding versus sad and deadly). For example, an article from August of 2018 I found on social media that left a big impression on me was "An Artist Painted a Self-portrait of Himself on a Different Drug Every Day-and He Ended up with Brain Damage" by Alison Millington. The piece provides the self-portraits that Bryan Lewis Saunders created in 2000. Each one is harshly different from the next depending on the drugs that Saunders had taken. These samples include Ritalin, marijuana, carbon monoxide, cough syrup, cocaine, and more. What is interesting is that probably his most "literary" portrait is from when he consumes opium. The image looks as though it is inspired by a widely-known portrait of William Shakespeare. What is more, the most disturbing image, in my own opinion, is the one produced by being drunk on alcohol. Unfortunately, 
Saunders suffered "psychomotor retardation and confusion." He is "still conducting this experiment but over greater lapses of time and presently only takes drugs that are prescribed to [him] by a doctor." Saunders candidly explores the ups and downs of drug through his own medium of understanding, his drawings.

Saunders' drug-inspired art, just like the opioid epidemic, is nothing new. In the Romantic and Victorian eras, it was popular to create art that incorporated representations of the poppy flower (from which opium is synthesized). Evidence of this exists in many works of art of the time, including Dante Gabriel Rossetti's famous "Beata Beatrix, (circa 1864-70)" in which the painter uses a likeness of his wife, Elizabeth Siddal, to represent the character of Dante's Beatrice. She is seen with a white poppy flower in her hand, representing laudanum, of which she died from an overdose (Rossetti Archive). Another painting of Rossetti's that contains a poppy flower is "Lady Lilith (1867)." This painting is full of flowers but most prominently and closest to the viewer is a large red poppy flower in a glass of water. Rossetti included a sonnet that is inscribed on the frame of the painting:

Of Adam's first wife, Lilith, it is told

(The witch he loved before the gift of Eve,)

That, ere the snake's, her sweet tongue could deceive, And her enchanted hair was the first gold.

And still she sits, young while the earth is old, And, subtly of herself contemplative, Draws men to watch the bright web she can weave, 
Till heart and body and life are in its hold.

The rose and poppy are her flowers; for where Is he not found, O Lilith, whom shed scent And soft-shed kisses and soft sleep shall snare? Lo! as that youth's eyes burned at thine, so went Thy spell through him, and left his straight neck bent And round his heart one strangling golden hair.

The lure and also results of opium use are easy to see in this poem. Lilith has the power to snare one into soft sleep and also strangle one's heart, just like addiction.

Similar to Rossetti's, John Keats' work was ripe with allusions to addiction. In Amelia Hill's article "John Keats Was an Opium Addict...," the author comments on Nicholas Roe's book which claims that Keats had a problem with opium that stemmed from him taking care of his ill brother. Roe states, My biography takes the contrary view that the spring of 1819 was not only one of Keats's most productive periods but also his most heavily opiated. He continued dosing himself to relieve his chronically sore throat; and that opium-induced mental instability helps to explain his jealous and vindictive mood swings regarding Fanny Brawne.

Roe also mentions that Keats may have become familiar with opium when he took care of his brother Tom who had tuberculosis and in turn John contracted the illness. In the popular poem "Ode to a Nightingale," readers can see some allusions to Keats' drug use. For example, the poem opens with, "My heart 
aches, and a drowsy numbness pains / My sense, as though of hemlock I had drunk, / Or emptied some dull opiate to the drains / One minute past, and Lethewards had sunk..." This is certainly where my eyes opened up to this specific topic. Though the poem is beautiful and often quoted, I sense a certain sadness and despair now when I read it, concerning what I know now about his private life. However, this also makes me feel a certain kinship towards him, now that I can view him as another flawed, sick, human being.

Another author, William Butler (W.B.) Yeats, was also no stranger to drugs. In the article "William Butler Yeats and Cannabis," Brian Houlihan notes that "Yeats was fascinated by the occult and spiritualism and he experimented with drugs. It is believed Yeats was first introduced to cannabis in 1890 through fellow writers in Paris. Yeats described some of his experiences in the autobiographic work 'Discoveries; A Volume of Essays.” Houlihan continues, "In the section entitled 'Concerning Saints and Artists' Yeats wrote about his first time trying cannabis":

I took the Indian hemp with certain followers of St. Martin on the ground floor of a house in the Latin Quarter. I had never taken it before, and was instructed by a boisterous young poet, whose English was no better than my French. He gave me a little pellet, if I am not forgetting, an hour before dinner, and another after we had dined together at some restaurant...I felt suddenly that a cloud I was looking at floated in an immense space, and for an instant my being rushed out, as it seemed, into that space with ecstasy. 
It is important to remember, that despite having experiences with drug use, Yeats was still able to be a successful writer, politician, and Nobel Prize winner.

\section{c. A New Crisis}

All told, I would not feel that I have done my due diligence with informing the reader if I did not include some facts about the current state of the opioid epidemic happening in our country. My extracurricular activities and volunteer work allow me a glimpse into the seedy underworld that is the American drug crisis. Within the scope of my extracurricular activities and volunteer work, I come across people every day who are affected by drug use. Similar to people of the Romantic era, new users came to be wrapped up in addiction through legal avenues. Many student athletes are prescribed powerful pain medications for sports injuries and end up becoming dependent on them. This can lead to acquiring other replacement street drugs when one cannot legally obtain prescription medications anymore. This is also common with the general public: People will be prescribed opioids, get hooked on them, and have to turn to unregulated street drugs when they cannot obtain legal drugs. According to the National Institute on Drug Abuse, over 115 people die of opioid overdose daily. This can be due to the misuse of both legally or illegally obtained drugs. About 20 to $30 \%$ of people who are prescribed opioid painkillers end up misusing them; almost $10 \%$ of them develop a misuse disorder, and approximately $5 \%$ transition to heroin. Shockingly, about $80 \%$ of people who use heroin misused prescription opioids first. These numbers are staggering and indicative of the systematic 
predicament we have in our country which entangles large pharmaceutical companies, healthcare providers, insurance companies, and citizens. This problem is not just left to "junkies" and addicts; it is a national problem that affects almost every citizen in some way. And because hypodermic needles often accompany certain types of drug use, the spread of diseases like HIV and Hepatitis has also risen, along with sexually transmitted infections.

Addiction is something that has always plagued humanity, and as we become more advanced, so do our drugs and addictions. One must remember that many of the greatest artists in history either dabbled in or were utterly addicted to drugs of all kinds. This is not to say that they were deficient, or their art is not worth experiencing. Rather, these artists were human beings, susceptible to a disease that we mere mortals are too. In that way, for me, it makes their work more approachable, because these esteemed artists were, in fact, like us. Artists like John Keats, W.B. Yeats, and more were all familiar with the impact that drugs had on the worlds inside and around them, and yet they pressed on and created works that are beloved till this day. Drug use disorders are a human issue, not a moral failing, and I think that can be clearly seen in these artists' works: They beautifully reflect the workings of the world in their own ways and at the same time create worlds that we can escape into, thus giving the audience their own dose of intoxication.

Understanding this link to the past is a way for current addicts to know that they are not alone and can go on to accomplish great things despite their disease. Like the authors mentioned in this chapter, I am trying to discover my 
own truth through my writing, similar to how Mary Shelley funneled her world into her book, some of which may have been influenced by her encounters with opium users.

The following chapters move past the more pressing questions like addiction and open up Frankenstein to modern performance interpretations, beginning with a discussion on the paradoxical cloud that seems to follow the myth wherever it goes. 


\section{PARADOXES: WHERE DO I BELONG IN THIS SCHEME OF LIFE?}

Mary Shelley's novel is busting at the seams with paradoxes. The audience sees this in Victor Frankenstein, a man who creates a monster, and in so doing, transforms himself into a monster; in the creature, who is kind to his (unbeknownst to them) host family but becomes a monster who destroys Victor's life because of a broken agreement. In 1818, Mary Shelley is a teenage girl but is also an experienced mother. The lasting legacy of Mary's story is also paradoxical. In "The Reading Monster," Patrick Brantlinger observes that in many film versions, "The Monster may be Victor's alter ego, his murderous phantom of Doppelganger, his Id or his petit objet a, even his 'subline object of ideology,' but it is only Victor who is identified with consciousness and, hence, with language" (475). And because the Monster is nameless and speechless, "it makes sense to give him his father-maker's name" (475), presenting us with a possible answer to question of which Frankenstein is which, the paradox of the named/nameless monster.

Switching from films to the novel, Brantlinger now reminds us that the reader never actually hears directly from the creature: "The Monster's narrative is filtered through Victor's, and both are in turn filtered through Robert Walton. That the Monster, though if anything more eloquent and rational than Victor (and Walton) encourages both his identification with his creator and the erasure of his demonic literacy, which is also his ability to represent himself" (475). The 
expressive and sensitive creature that we came to know in the novel is but a voice within and voice within a voice.

Continuing this conversation, Garrett Stewart, in "In the Absence of Audience," suggests

that at some level the reading that brings the Creature to compelled and compelling voice, the reading aloud at the de Lacey cottage, is what "humanizes" him. So, too, with reading by Mary Shelley that went into his imaginative composition. Refrained thrice over by the novel's layered textural dissemination, the Creature erupts as a perversely fashioned organic entity in every sense brought alive by reading: Shelley's, Victor's, the cottagers', the Creature's own, Walton's, Mrs. Saville's prospectively, and finally in the moment of extrapolation from all of them, your own. (443)

Even though the creature is, in essence, voiceless, the combination of characters and reader give him a voice and therefore bring him to life. Mary's paradoxes leave readers uneasy and sometimes confused by their own feelings towards the characters; we begin to question human nature and creation.

\section{a. She's Alive! Alive!}

In the 1935 film, Bride of Frankenstein, actor Elsa Lanchester plays Mary Shelley. One scene shows Mary sitting on a couch, rather intimately, with Lord Byron and Percy Shelley, discussing what spooky tales they will write. Mary's character professes that "An audience needs something stronger than a pretty 
little love story. So, why shouldn't I write of monsters?" For the plot of this movie, Director James Whale supposes that the titular characters from the first movie, Frankenstein (1931) live on to meet again so that Henry (representing Victor's character from the book) can finally build a companion for the creature. The actor who plays the bride is not credited so that the audience is left wondering who this new monster is, but she is actually played by Elsa Lanchester! Famously, the bride does not communicate with words; instead, she screeches when introduced to her mate.

Inasmuch as the creature is a paradox, so is his mate. Lanchester playing both roles, the well-spoken Mary and the bride who only screams, reminds me of how talented Mary was yet how little agency she had over her work:

Frankenstein was anonymously published at first. In "The Reception of Frankenstein," Chris Baldick suggests that "The novel did not appear under Mary Shelley's own name until the second edition in 1823, so the only clue which readers had in 1818 about the anonymous author lay in the dedication to William Godwin" (242). This left critics to assume that Percy Shelley had written the book, or if not him then some other man, of course.

Recalling "The Power of Contemporary Science," the author reasons that "the scene on the Mer de Glace in which [the creature] begs Frankenstein to create a wife for him is central to his search for human identity and happiness. The clear implication is that a fully human 'soul' can only be created through friendship and love..." (190). This appeal made by the creature to Victor for a 
mate is revivified in Bride of Frankenstein. Woefully, the creature's sole request for happiness is snatched from him (and us) when we realize that the name of the film is not indicative of how the narrative plays out. The paradox of a bride who is mortified by her intended suitor is observed when the bride's blood curdling screams are heard when the creature asks "friend?" while stroking her hand.

b. It's Alive! It's Alive!

From the novel to Frankenstein (1931) then Bride of Frankenstein (1935), the creature devolves from articulate and compassionate to a character with no words to express himself, then slightly evolves again to having some rudimentary language. Boris Karloff, who played the creature in both of the films, is rumored to have regretted the bits of language he used in Bride. Because of all of these factors, the creature exists in my mind in several ways concurrently. He is capable of eloquently reciting poetry and grumbling in baby talk; able to scale mountains in the blink of an eye and shuffling uncomfortably in his almost-human body.

Furthermore, besides some short descriptions, Mary Shelley gives us precious little to go by in the way of physical description of the creature. Readers are left alone with their imaginations to concoct monstrous images; film directors must form their own patchwork beings based on the what Mary's myth evokes in them. The creature exists as both what we have dreamed up while reading and what pop culture has bombarded us with. In an article by James A. W. Heffernan, 
the author emphasizes that "a faithful re-creation of the novel's central narrative, in fact, would never show the monster at all-would give us only the sound of his voice over shots of what he perceives..." (450). This is reminiscent of the "viral" Netflix movie, Birdbox (2018), in which the monsters that cause people to commit suicide are never shown on screen. Opinions were divided on whether this was a favorable tactic, so I do not know how well this might work with a new rendition of Frankenstein. Maybe one day we will find out.

Since the topics of films and pop culture have been touched upon here, the next section delves deeper into the aforementioned 1931 film version of Frankenstein and more. 


\section{POP CULTURE}

Many people today see Frankenstein's creature as the giant, green troublemaker who must be chased away from civilization. Victor is now the quintessential mad scientist; the creature is named Frankenstein.

In "Mary Shelley and the Power of Contemporary Science" by Richard Holmes, the author explains how this transition came about:

The novel itself disappeared into temporary obscurity, and fewer than 500 copies were sold of the first edition. But it was made famous, if not notorious, in the 1820 s by no less than five adaptations for the stage. These caused widespread controversy. The first was staged in London in 1823...entitled portentously Presumption: or The Fate of Frankenstein.

This play made major edits to the original content. Mary Shelley was never asked permission, credited, or given any royalties, but, "Curiously, she did not seem to mind, and when she herself went to see the play in September 1823 she loved it" (192). Mary even left a very kind review of the play! Unfortunately, "The changes have influenced almost all subsequent stage and film productions. They altered the scientific and moral themes of the book...Victor Frankenstein is made the archetypal mad and evil scientist" (Holmes 192). Victor's laboratory becomes a place full of noisy science equipment. He is also given a bumbling assistant named Fritz (becoming Igor in later iterations). Holmes believes that this removes the artistic element of Victor's creativity and transforms it into a spectacle, since in the novel, Victor more delicately "works by candlelight at a surgical table" 
(192). Holmes asserts that "the most important change of all [from the novel to the plays] is this: Mary Shelley's unnamed Creature is transformed into the 'Monster', and made completely dumb. He is deprived of all words, whereas in the novel he is superbly and even tragically articulate..." (193).

a. I Am Thy Creature

It appears to me that every incarnation of Mary Shelley's tale after its creation has either aimed to humanize or dehumanize the creature. Playwrights and film directors fashion their own creatures and decide whether to follow the path of Mary's novel, or the plays which strayed from the original content.

When it comes to film and television adaptations, we must first ponder why it even matters that we analyze these new versions. Well, for one, because it is simply fascinating to realize that Mary's influences have stretched 200 years beyond the original publication of her book. Moreover, studying these adaptations allows us to peek into the minds of the directors to see what they gained from the original tale and how they wish to represent their own monsters. In the article "Looking at the Monster: Frankenstein and Film" by James A. Heffernan, the author suggests that "this myth of miscreation, of artistic ambition run monstrously awry, that scores of filmmakers have sought to illuminate in their own art-[is] an art which may yet lead us to a deeper understanding of Mary Shelley's" (453). Hence, in examining how the myth has evolved, readers may begin to appreciate the original work in new ways.

In my own experience, I saw many pop culture versions of Frankenstein before I read the book in graduate school. Learning about the original story was 
truly eye-opening. Many things I thought I knew were incorrect, but all those references that I had grown up with were what I took with me into reading the novel, and that helped me appreciate it even more. However, looking at my scope of references which includes the films, cartoons, the book, and other adaptations, I have noticed that of course the creature is treated differently by each new creator, but these differences are mostly reflected in what level of humanity the monster is granted.

b. I Was Benevolent

The first time I came across anything Frankenstein-related that I can remember is the television program The Munsters. I watched reruns that were originally aired in 1964-1966 ("The Munsters"). The show is about a family of various creatures commonly seen in horror movies, like Dracula, a vampire, a werewolf, and Frankenstein's creature. Of course, a beautiful, very humanlooking niece is included, but is often distraught because she is the "weird" or "ugly" one of the family. Hilarity ensues. Throughout the episodes, this family who lives in a creaky gothic home at 1313 Mockingbird Lane goes about their business of being the typical American family: work, chores, school, spending time together. It is not until they are met by the outside world that the identity of monstrosity is put upon them by others; however, they are comically unaware of how different they are from their neighbors or why everybody is afraid of them. This series plays up the idea that monsters can be "normal" on the inside (of the house) and scary (looking) on the outside. 
One telling episode of the show is "Low-Cal Munster" from 1964. Fred Gwynne plays Herman Munster, whose character design is adapted from Boris Karloff's 1931 version of Frankenstein's monster (more on this film in the next section). In this episode, Herman, goes in for a physical exam with the family doctor. Dr. Dudley, actor Paul Lynde, has given his glasses to his nurse to be repaired, so when Herman enters the office, the doctor cannot clearly see him and treats him rather normally albeit hilariously (e.g., the doctor thinks Herman's hairy hand is a dog). This scene can be compared to when Victor Frankenstein's creature in the novel finally visits Mr. DeLacey, who is blind, and sparks a friendship. They have a pleasant time together until the old man's sighted children arrive home and drive the creature away, of course.

In one of the most popular modern adaptations of Mary's tale, Young Frankenstein (1974), director Mel Brooks stitches together his own monster of comic proportions; the film even comes in at unlucky number 13 of the American Film Institute's ranking of the 100 funniest films (LaGrandeur). In the article "Frankenstein, Young and Old: An Interview with Mel Brooks" by Kevin LaGrandeur, the author sits down with the legendary comedian actor/director to find out more about the whys and hows of Young Frankenstein. When asked if he had any doubt about taking on such a "huge and famous" story like Mary's novel, Brooks responds, "Well, I was a fan of the Mary Shelley book. I had read it when I was a kid, and I read it again when I was a little older, when I was in the army, actually. I was amazed at the eighteen-year-old girl coming up with this incredibly brilliant idea. And at how well-written it was" (87). Throughout the rest 
of the interview, Brooks remembers that he tried to pay homage to Mary's book as much as possible, while still using some influences of James Whale's 1931 film: "I think that Whale made the most beautiful movie rendering of Frankenstein. Boris Karloff's performance as the monster was incredible, and Colin [Clive] as Victor Frankenstein was too. It was a great movie, but I think we were more faithful to Shelley's book itself and to her spirit. We wanted to do that" (91). In keeping more in step with the themes of Mary's novel, Brooks was able to humanize his creature in many ways. By the end of the movie, the creature "gives a speech that is so incredibly intelligent and beautiful, it's almost like one of Shakespeare's monologues. At that moment, [the] creature becomes similar to the creature in Shelley's book, who is a genius of sorts..." (90). As fate and history would have it, unfortunately, this is not always the case in film adaptations of the book.

\section{c. Abhor Me}

The other side of the Frankenstein coin is that filmmakers can choose to derive their material based on the plays that came after the publication of Mary's novel, and in so doing, tend to make the monster less than human or even supernatural. One case of this is director James Whale's 1931 film starring Boris Karloff as the monster. The visual representation of Victor's creation in this movie is arguably one of the most recognizable versions, and renditions are still seen today: square-head, gray-green skin, sunken eyes, a black suit. In fact, I dressed as Boris Karloff's creature for Halloween once and was immediately recognized as "Frankenstein," but I did not have the guts to correct anybody that night, of 
course. Whale's interpretation of the myth is different from Brooks' in that he seems to intend to make Karloff's character send the audience into hysterics instead of evoking compassion.

A special-edition of Life Magazine that celebrates 200 years ("Still Crazy After All These Years") since the publication of Frankenstein, pulls the history of the novel and Mary's life together with pop culture and beyond, and provides a look into the terrifying movie magic of Whale's film. In an illustration of the title card for the 1951 rerelease, the movie is credited as "The thrill chill story of all time! It will make your blood run cold!" (45). Whale is also quoted as saying "I thought [the film] might just as well be as horrible as possible" (48). Nevertheless, viewers cannot deny feeling pity in seeing the creature's sad gaze. Karloff understood the necessity for eliciting compassion from the audience, so he helped with his makeup. He recalls, "We found the eyes were too bright, seemed too understanding, where dumb bewilderment was so essential...so I waxed my eyes to make them heavy, half-seeing" (53). Karloff helped create a monster that was stirring in more ways than just horror. In a memorable scene where the monster makes friends with a little girl who is picking daisies and throwing them in the water, it is rumored that the actor defied Whale's wishes of violently throwing the girl into the water, instead opting for a more child-like approach to make it seem as though the monster assumed the little girl would float as the daisies did. Though a variety of films would follow this one, it remains one of the most influential. Jack Pierce's makeup and costuming design for Whale's vision of a monster still echo through to 2019. 
Admittedly, it would only seem appropriate that I would round out this section with a personal connection to the 1931 film. In a cosmic turn of events, I found out that Boris Karloff, like me, had Eastern Indian heritage. According to a website dedicated to Karloff and maintained by his family, Rhonda Steerer states that the reason why the actor may not have gotten better work throughout his acting career before Frankenstein, despite his talent, was because of, as he referred to it, his "tan." He was often cast as the villain or some other "exotic" bit character. It took the industry 20 years to recognize that Karloff was worth taking a shot on. It is tragic that the horror star had to endure many years of discrimination, but it is amazing to consider what a legacy he left behind when he finally became famous, even if his fame was for being a monster!

When I found out about Karloff's cultural background, I asked myself, is it possible that Boris Karloff, one of my horror idols, could have had the same feelings I do about our shared heritage? Did he sometimes feel uncomfortable because of his skin tone? Did he feel like a monster before he played one? It is reassuring that Boris Karloff may have been, even just a little bit, like me. 


\section{LOST IN DARKNESS AND DISTANCE}

Respecting that I am a monster has been the most impactful thing that I have realized within my tenure as a master's candidate in the Florida International University English Department. I am a synthesis of identities: I am a person in recovery, a student, teacher, White, Indian, and more. To wit, Mary Shelley's Frankenstein along with some other insightful literature have been my guides to self-reflection and thus self-discovery, and a personal redefining of what monstrosity means. In an address that Inaugural Poet and FIU alumnus Richard Blanco recently gave on campus, he noted, "I am, because we all are, and together we rise, despite everything trying to keep us from rising." This is poignant because of the blending of the "I" and "we." Miami is a singular city that exists in innumerable ways to its people. In spite of everything that tries to hold us back, mostly ourselves, we have shaped our separate identities into one Miami, with the individual pieces still visible. This is how I am beginning to view myself: as a singular, worthy, human being who is assembled from pieces that may not always work together, but somehow make a beautifully monstrous mosaic.

In the Kevin LaGrandeur interview with Mel Brooks, the author asks the director, "If Mary Shelley were here right now, and you could say anything you wanted to about your movie or her book, what would you say to her?" Brooks answers, 
I'd probably say, "Miss Wollstonecraft, you're a genius..." I would hug her, and kiss her, and tell her what an inspired story she wrote and what a genius she was, to write something so imaginative and creative and profound, at such an early age. I would tell her how grateful we all are for her genius, her gift. That's what I would have said... (102).

And you know what, I would too. 


\section{REFERENCES}

"About." The Royal Institution: Science Lives Here, www.rigb.org.

"Addiction." Encyclopedia Britannica, Encyclopedia Britannica, Inc., www.britannica.com/science/addiction.

Baldick, Chris. "The Reception of Frankenstein." Frankenstein, by Mary Shelley, Norton, 2012, pp. 242-248.

Bechtel, William, and Robert C. Richardson. "Vitalism." William Bechtel, University of California, San Diego, 1998, mechanism.ucsd.edu/teaching/philbio/vitalism.htm.

Blanco, Richard. "Next Horizons." 26 Jan. 2019, Miami, Florida International University.

Brantlinger, Patrick. "The Reading Monster." Frankenstein, by Mary Shelley, Norton, 2012, pp. 468-476.

Butler, Marilyn. "Frankenstein and Radical Science." Frankenstein, 2nd ed., Norton, 2012, pp. 404-416.

Coleridge, Samuel Taylor. "Kubla Khan." Poetry Foundation, Poetry Foundation, www.poetryfoundation.org/poems/43991/kubla-khan.

"Electrolysis." Encyclopedia Britannica, www.britannica.com/science/electrolysis.

Firmat, Gustavo Perez. Life on the Hyphen: The Cuban-American Way. University of Texas Press, 2012.

Franklin, Ruth. "Was Frankenstein Really About Childbirth?" New Republic, 7 Mar. 2012, newrepublic.com/article/101435/mary-shelley-frankenstein godwin-bodleian-oxford.

Gilbert, Sandra M., and Susan Gubar. "Mary Shelley's Monstrous Eve." Frankenstein, 2nd ed., Norton, 2012, pp. 328-344.

Goehner, Amy Lennard. "Frankenstein Becomes a Star." Life: 200 Years of Frankenstein, pp. 36-67.

Hartney, Elizabeth, and Steven Gans. "What Are Some Criteria for Substance Use Disorders?" www.verywellmind.com/dsm-5-criteria-for-substanceusedisorders-21926. 
Heffernan, James A. W. "Looking at the Monster: Frankenstein and Film." Frankenstein, 2nd ed., edited by J. Paul Hunter. by Mary Wollstonecraft Shelley, Norton, 2012, pp. 444-467.

Hill, Amelia. "John Keats Was an Opium Addict, Claims a New Biography of the Poet." The Guardian, Guardian News and Media, 21 Sept. 2012,www.theguardian.com/books/2012/sep/21/john-keats-opium-addict.

Hirsch, Brett D. "Counterfeit Professions: Jewish Daughters and the Drama of Failed Conversion in Marlowe's The Jew of Malta and Shakespeare's The Merchant of Venice." Early Modern Literary Studies, vol. 12, no. 19, Nov. 2009.

Holmes, Richard. "Mary Shelley and the Power of Contemporary Science." Frankenstein, $2^{\text {nd }}$, ed., Norton, 2012, pp. 183-194.

Houlihan, Brian. "William Butler Yeats and Cannabis." Medium.com, Medium, 3 June 2017, medium.com/@dubhempmuseum/william-butler-yeats-and-cannabisfa8335789c37.

John Keats. "Ode to a Nightingale." John Keats: Complete Poems, Harvard University Press, 1982, pp. 282-281.

LaGrandeur, Kevin. "Frankenstein, Young and Old." Frankenstein: How a Monster Became an Icon, edited by Sidney Perkowitz and Eddy Von Mueller, Pegasus Books, 2018, pp. 84-104.

Meier, Allison. "The Secret Victorian Language of Flowers." Hyperallergic, 3 June 2014, hyperallergic.com/129541/the-secret-victorian-language-of-flowers/.

Moers, Ellen. "Female Gothic: The Monster's Mother." Frankenstein, 2nd ed., Norton, 2012, pp. 317-327.

"The Munsters." IMDb, IMDb.com, www.imdb.com/title/tt0057773/.

“'The Munsters' Low-Cal Munster." IMDb, IMDb.com, www.imdb.com/title/tt0653086/.

National Institute on Drug Abuse. "Opioid Overdose Crisis." NIDA, 6 Mar. 2018, www.drugabuse.gov/drugs-abuse/opioids/opioid-overdose-crisis.

Ortis, Laura. "Frankenstein: Representing the Emotions of Unwanted Creatures." Frankenstein: How a Monster Became an Icon, edited by Sidney Perkowitz and Eddie Von Mueller, Pegasus Books, 2018, pp. 18-37.

Pirie, David, and Mary Shelley. "Approaches to Frankenstein [in Film]." 
Frankenstein. 2nd ed., Norton, 2012, pp. 276-287.

Rossetti, Dante Gabriel. "Beata Beatrix." Tate, www.tate.org.uk/art/artworks/rossetti-beata-beatrix-n01279.

Rossetti, Dante Gabriel. "Lady Lilith." Rossetti Archive, www.rossettiarchive.org/docs/s205.rap.html.

Ruston, Sharon. "Representations of Drugs in 19th-Century Literature." The British Library, The British Library, 7 Mar. 2014, www.bl.uk/romantics-and-victorians/articles/representations-of-drugs-in-19thcentury-literature.

Shakespeare, William. No Fear Shakespeare: The Merchant of Venice. Edited by John Crowther, SparkNotes, 2003.

Shelley, Mary, and James P. Hunter. Frankenstein. 2nd ed., Norton, 2012.

Shelley, Mary. "Introduction to Frankenstein, Third Edition (1831)." Frankenstein. 2nd ed., Norton, 2012, pp. 165-169.

"Sir Humphry Davy." Encyclopedia Britannica www.britannica.com/biography/Sir-Humphry-Davy-Baronet.

St. Clair, William, and Mary Shelley. "Frankenstein's Impact." Frankenstein, $2^{\text {nd }}$ ed., Norton, 2012, pp. 248-262.

Steerer, Rhonda. "The Soft Side of Boris." The Official Boris Karloff Web Site, www.karloff.com/?page_id=1439.

Stewart, Garrett. "In the Absence of Audience: Of Reading and Dread in Mary Shelley." Frankenstein, by Mary Shelley, Norton, 2012, pp. 434-443.

Stovall, Colleen. "Why This Play? Why Now?" Shakespeare Miami, www.shakespearemiami.com/is-the-merchant-of-venice-antisemi.

"What Is Addiction?" American Psychiatric Association, www.psychiatry.org/patients-families/addiction/what-is-addiction.

"William Godwin." Encyclopedia Britannica, Britannica, www.britannica.com/biography/William-Godwin.

Zerivitz, Marcia Jo. "Miami's Jewish History." Greater Miami Jewish Federation, jewishmiami.org/about/federation/miami_jewish_history/. 